\title{
Equilibrium
}

Quarterly Journal of Economics and Economic Policy

VOLUME 8 ISSUE 1, 2013

ISSN 1689-765X

Paweł Galiński*

University of Gdańsk, Poland

\section{Activity of Microfinance Institutions in the Period of the Global Financial Crisis}

JEL Classification: $G 21, G 23, F 63$.

Keywords: microfinance institutions, loans, deposits

\begin{abstract}
The article examines the models of microfinance institutions (MFIs) and some alterations in this field. The regional distribution of MFIs has been shown, as well as their main ties with the real economy against a background of commercial banks. The study also provide some findings on the influence of the financial crisis, which erupted in the late 2007, on the microfinance sector. Therefore, the author analyzed the literature and quantitative data in order to determine these relationships.
\end{abstract}

\section{Introduction}

The influence of microfinance in the world has already been spread. In the era of globalisation, in many, especially poor countries, a tiny minority of population benefits from this trend. Furthermore, internationally operating financial institutions, particularly banks, are keen on keeping massive and large sum operations, belittling households and microfirms in terms of capi-

(C) Copyright Polish Economic Society Branch in Torun

Date of Submission: December 12, 2011; date of acceptance: February 13, 2013

* Contact: e-mail: p.galinski@wp.pl, University of Gdańsk, Faculty of Management, Department of Finance, Faculty of Management, ul. Armii Krajowej 101, 80-824 Sopot, Poland 
tal access. Microfinance, by providing access to loans and technical assistance for those financially excluded, challenges and helps reverse this trend. Therefore, microfinance has an excellent future, not only in poor countries but also in the developing ones or industrialised world (Forest et al. 2003, pp. viii). It resulted from the fact that there are some constraints for households, microenterprises or even for many small and medium sized enterprises (SMEs) to develop properly. First of all, it is a shortage of capital, which could have been accessible for them. Banking sector is not favourable to finance lots of households and microenterprises due to the lack of financial history and collaterals by them. However, the importance of the microfinance for the development of the poor countries and its growth may be disrupted by the global financial crisis that erupted in late 2007. Thus, the aim of this paper is to characterise the activity of the microfinance institutions (MFIs) between 2007 and 2010, simultaneously indicating some financial and economic issues determining their functioning in the countries. Moreover, theoretical aspects of the microfinance were shown, as well as their main differences comparing to the banking sector and their meaning for the economy from the regional perspective.

\section{The concept of Microfinance}

The concept of microfinance has its basics in the statement that the lack in the access to credits and other financial services is the key development limitation for the individuals who are poor and devoid of income. This group includes micro entrepreneurs and unemployed, especially from rural and small urban areas. Therefore, microcredit is emphasised as a fundamental tool for supporting them. Furthermore, microcredit is attractive for those who have never collaborated with financial institutions before, especially with commercial banks. Lots of research in the field of microfinance indicate their positive influence on living conditions of the poor. Regardless, A. Karnani found that although activity of MFIs achieve some benefits, they do not significantly eradicate poverty (Welle-Strand et al. 2010, p. 15). In his opinion, mainly a steady employment at reasonable wage is the best way to take people out of the poverty (Karnani 2008, p. 62). Furthermore, loans of MFIs are more beneficial to borrowers living above poverty line rather than to people living below this indicator (Karnani 2007, p. 36).

To recapitulate, microfinance is a collection of institutions and financial instruments provided by them which are accessible, especially for the poor, in order to protect, support and promote business activity and combat poverty. 
The fundamental difference between microfinance and commercial banking sector lies in the fact that MFIs do not require collaterals in their conventional form (Carboni et al. 2010, p. 10). Lots of MFIs, aside from typical financial services, such as credits and savings (Ledgerwood 1999, p. 1), also provide social services, such as health care and educational ones for the underprivileged. As a result, they are not always perceived as profitmaximizing financial institutions (Sengupta, Aubuchon 2008, p. 10). On the other hand, rapid development of the microfinance sector causes some alteration in their capital, transforming them from donor-founded entities into financially-sustainable microcredit organizations, which are supported by the investors (Welle-Strand et al. 2010, p. 146). Microfinance owes a lot to international donors (non-profit organisations) whose capital aims to maximize social benefits in line with their charitable mission. Investors, in turn, seek to maximize return on their capital and weigh risk against potential profits. There are many kinds of participants in the microfinance success, such as: wealth individuals, insurance companies, pension funds, commercial bank or even investment banks (Tulchin 2004, pp. 2-3). Their engagement usually changes the core idea of MFIs functioning from social to profit-oriented.

But even without MFIs, poor households have the alternative access to sources of capital. In a 1990 survey carried out in rural Indonesia reports that as many as $70 \%$ of the interviewed households borrowed from informal lenders (Armendáriz de Aghion, Mordoch 2005, p. 57). The problem is the level of interest rate of that loan. In a sample of 44 countries worldwide examined by the World Bank in 1984, the average interest rate of the loan was $11 \%$ in the formal sector comparing to $95 \%$ in the informal market (Helmor et al. 2009, p. 10). That's why MFIs, which grant loans at a similar level as commercial banks do, could positively determine financial security of the low-income borrowers.

\section{Models and Range of Microfinance Activity}

Many differences among microfinance institutions (MFIs) between the countries have been distinguished. It depends on the legal and economic system or social and political conditions in each economy, where MFIs operate. Moreover, every MFI has its own governance and capital structure, which influence products and services they deliver to clients. Therefore, MFIs may be differentiated, as follows:

- Credit Unions,

- Non-governmental Organizations, 
- Private Firms,

- Banks (Downscaling Commercial Banks, Microfinance Banks).

Credit Unions (CU) are typically founded under special legislation. Their members who simultaneously are $\mathrm{CU}$ customers accountable to this institution own them. Membership in a $\mathrm{CU}$ is based on the principle of a common bond - at least one declared, common characteristic. It ensures a certain level of solidarity and a sense of belonging among the members, which positively affects keeping loan delinquency low through peer pressure. There are typical common bonds, such as: geographic location, workplace or professional associations.

CUs are distinguished from other MFI types due to the fact that they are usually "savings-first" institutions. Then, the capital base gathered in this way is allocated in the lending activity. Moreover, being part of national or international associations, CU may borrow funds from them to increase lending capital (Forest et al. 2003, p. 17). CUs generally target low-income people, who in many cases are unwanted bank's clients.

CUs offer a lot of various products and services, such as: personal account, loans, credits, deposits, credit cards, and ATM's services. It is also possible to invest money in money market.

Nongovernmental Organizations (NGOs) have developed, in turn, as crucial providers of microfinance in many parts of the world. In general, the mission of this type of microfinance institutions is to provide an access to credit and other services to the self-employed and micro-firms. They have chosen to operate through financial products and services in order to achieve social benefits, such as: job creation, income growth, increase of living standards, etc.

NGOs are usually established as foundations or associations. A foundation (also known as a "fund" in some countries) consists of capital donated by one or more founders, who dedicate its usage to one or more specific goals. On the other hand, an association is characterized as an institution established by their members who share a common purpose. There are also a few credit-only NGO microfinance institutions licensed as companies. All NGOs, even if they are non-profit, are due to be financially self-sufficient and raise a substantial net income.

These organizations target poor people, in many cases, engaging in informal-sector activities. Moreover, they aim their offer at microenterprises, as customers that often operate in the low-income segments of business activity (Forest et al. 2003, pp. 19-21).

As far as private firms are concerned, they target especially low-income households, which have no access to banking credits. They operate through their branches, representatives as well as through close cooperation with 
shops, offering various kinds of loans, leasing, etc. Private firms are estabestablished by people who have chosen financial sector to generate profit. In many cases, they are parts of international institutions or national financial groups, therefore, they may borrow money from the centre for the loan activity.

Analysing the banking sector, two types of banks in the field of microfinance are distinguished: Downscaling Commercial Banks and Microfinance Banks. The model of downscaling approach of banks was initiated by the Inter-American Development Bank (IDB) in the early 1990s. IDB introduced programmes that provided credit lines to select commercial banks for the lending purpose to microenterprises. This activity also included technical assistance for each co-operator bank, which was aimed at training in the field of micro lending techniques and micro lending performance monitoring system (Forest et al. 2003, p. 24).

Hence, the group of downscaling banks includes some traditional banks, which developed products or created subsidiaries to serve low-income communities. They are involved in microfinance in order to reach a good public image (large mainstream banks) or obtain attractive market niche (smaller banks) (Churchill, Frankiewicz 2006, p. 28).

Downscaling Commercial Banks may reach a success because of the following facts:

- they may use large branch networks to serve customers and transfer funds;

- the use of commercial banks' know-how and experience with credit operations would allow microfinance activity to become widespread and profitable;

- commercial banks may tailor full range of financial services, including deposit facilities, money transfers, fund management, etc., to microfinance individuals.

However, it is not clear whether Downscaling Commercial Banks have intergraded microfinance activity into their overall strategic vision. In many cases, microfinance is a programme with the mission of serving micro and small firms with the access to credit. Therefore, they operate primarily registered, experienced and growth potential micro and small enterprises, mainly from the urban areas (Forest et al. 2003, pp. 23-26).

On the other hand, microfinance banks are the newest entrants into the microfinance sector. They are licensed to serve micro and small business from the beginning to its activity. Some strategies of their activity envisage a public-private partnership as an amalgamation of international financial institutions, private-sector institutions and public institutions. The goal of this model is to meet financial and social expectations and achieve credibility of the local community. Thus, the mission of microfinance bank 
is to serve micro and small enterprises along with gaining positive returns on shareholder equity (Forest et al. 2003, pp. 27-28).

Activity of bulk of institutions which offer capital for the poor cause some imprecisions in the microfinance terminology. It resulted from the fact that not only the type of clientele but also other issues determine whether or not it is the MFI. So, in the literature and in practice, there may by distinguished alternative financial institutions (AFIs) and their types, such as:

- MFIs,

- Financial cooperatives/mutuals,

- Low-capital rural and/or local banks,

- State agricultural and development banks,

- Postal savings banks.

The main difference between MFIs and AFIs is the type of clients, which they operate. MFIs tend to be more focused on the poor and near-poor, whereas AFIs are aimed at the unbanked people. That's why MFIs clients are poorer comparing to the other AFIs in the same country (Christen 2004, p. 2).

Other classification of institutions which serving the microenterprise sector distinguishes:

- Multipurpose Financial Institutions,

- Specialized Financial Institutions,

- Specialized Non-Governmental Organizations,

- General Non-Governmental Organizations.

The first two kinds of institutions are mainly banks or finance companies, whereas the others are the foundations or associations. They mainly differ in the range of clients, services and sources of capital for their activity. So, multipurpose financial institutions and specialized non-governmental organizations are diverse in these aspects (Jansson 2001, p. 2).

In turn, M. Holtmann includes the following to the major types of MFIs (Holtmann 2008, p. 160):

- non-governmental organizations;

- "greenfield banks";

- alternative financial institutions such as:

a. savings banks;

b. cooperatives;

c. state-owned postal banks.

According to the African experience, of the microfinance these types of institutions fall into five main categories (Helmore 2009, p. 19):

- microfinance banks, which are govern by the same regulations as commercial banks; 
- rural banks and community banks;

- cooperative networks;

- non-governmental organizations, engaged especially in the credit activity;

- non-banking financial institutions, which are for-profit enterprises, that are not registered as commercial banks because of lower capital requirements.

The crucial factor of the development of microfinance in the world is also the engagement of the European Union. Within this organisation and other countries, microfinance operations are carried by the European Investment Fund (EIF). It offers a broad range of products for eligible intermediaries, such as: senior and subordinated loans, risk-sharing loans, equity participations or some types of guarantees (The EIB... 2011, p. 3). These instrument may be used by entities which are engaged in microfinance and want to broaden their activity.

The differentiation of MFIs between the countries results also from the strong expansion of these institutions in the last three decades. When microfinance initiated to expand during the 1980s, almost the only goal was the lending to the rural poor for income-generating purposes. At the early stages of the market, microcredit was provided mainly by donor-supported non-profit NGOs. Since then, microfinance has evolved into a more comprehensive development instrument aimed at supplying access to financial services for all unbanked people in emerging and developing markets. It expanded also into new segments or group of clients and grew into a more commercialized industry. Only between 2002 and 2010 in the Latin America, Eastern Europe and Central Asia and the Middle East and North Africa in MFIs average loan size doubled, which partly reflects the increasing share of wealthier borrowers (Lützenkirchen, Weistroffer 2012, pp. 3-4).

In order to widen their activity and maximize profit of the investors, MFIs search for new sources of capital. In April 2006, Blue Orchard (wholesale lender to MFIs) executed the largest single commercial investment transaction in the history of microfinance. It was a form of a collateralized loan obligation. This transaction comprised a raise of 99 million USD for 21 MFIs in 13 different countries in five different currencies. In May 2007, similar transaction was priced at a 110 million USD equivalent of unsecured loans to 20 MFIs in 12 countries and was rated by Standard \& Poor's. There were milestones for the microfinance in the process of their development. Beside these types of transactions, some MFIs launched the emission of their shares on the stock exchanges (Davis, Dubitsky 2013). 


\section{Main Differences Between the Activity of Microfinance Institutions and Commercial Banks}

Unlike many commercial banks or even financial cooperatives, MFIs apply simplified form of money lending because of limiting the process of credit scoring. Loan officers who represent MFIs rely usually on their experience and other qualitative aspects (eg. personal character of the borrower), rather than quantitative data. It resulted from the fact that the bulk of their borrowers cannot, as it was mentioned, document income and credit history. Nevertheless, properly used credit scoring decreases arrears while increasing profits and number of clients including the poor ones (Dellien, Schreiner 2005, pp. 1-2). That's why some differences may be distinguished between microfinance lending and banking lending principles, such as (Dellien, Schreiner 2005, pp. 1-3):

- MFIs assess risk implicitly and variably rather than explicitly and consistently;

- MFIs rely on qualitative issues rather than produce quantitative risk forecasts;

- MFIs use the experience of the loan officer rather than the whole organization;

- MFIs apply pass/fail rules of granting the loan rather than allow "lowrisk" attributes to compensate for "high-risk" attributes.

Since the MFIs usually apply above principles, their loan officers spend a lot of time on collections. Moreover, they are responsible for tackling each loan through constant performance reports (Dellien et al. 2005, p. 4). For example: in Columbia loan officers spend about two days per week on evaluations, one day on office work and two days on collections (Dellien, Schreiner 2005, pp. 12-13).

The credit activity of the MFIs is also determined by the economic, social and legal issues of each country they operate in. In contrast to banks, nonbanks are more focused on rural areas, where, in many cases, there may by some constraints to reach potential borrowers. MFIs do not possess, comparing to commercial banks, the large branch network. Thus, they operate by the agency of their representatives - loan officers.

In many countries the functioning of MFIs, in contrast to banks, is limited. It concerns especially the deposit activity. However, there are countries where microfinance sector is not regulated by the supervisory agency. It includes, inter alia, the economy of Bangladesh, Honduras, Malaysia or Tajikistan (Financial... 2010, p. 63). 


\section{Microfinance Against a Background of Banking Sector Between 2007 and 2010 - Characteristics and Barriers of Development}

The global financial crisis has changed preferences and abilities both the financial institutions and their clients between 2007 and 2010. In 2009, about $60 \%$ of economies experienced a decline in real gross domestic product (GDP) per capita. Worse macroeconomic conditions affected, inter alia, the volume of deposits and loans around the globe. Between 2008 and 2009 in the world the deposits as a percentage of GDP declined from $72 \%$ to $66 \%$. In this period, the ratio of commercial bank deposits to GDP fell by $11.8 \%$, whereas the number of deposits accounts per thousand of adults rose by $4.3 \%$. Thus, $49 \%$ of households has deposit accounts in formal financial institution in the world (Financial... 2010, pp. 5-7). However, alterations in the number of deposit accounts differed substantially across the world. In Europe and Central Asia, commercial bank deposits to GDP and number of deposits per thousand adults dropped by 22 and 1\%, while in South Asia rose they by 2 and $1 \%$. But the largest increases of the number of deposits per thousand adults were in Latin America and the Caribbean region (8\%), and Sub-Saharan Africa region (8\%). Despite these changes, the majority of deposit volume was located in commercial banks. In 2009 only $15 \%$ of them, $13 \%$ individual deposits and $2 \%$ business deposits, were in non-bank institutions. It resulted from the fact that in most of economies, as it was mentioned, legal frameworks do not allow MFIs to take deposits. There are some exceptions, such as Spain, France, Chile or Burundi, where cooperatives and specialized state financial institutions hold more deposit accounts than commercial banks. Similar situation takes place in West African countries (Financial... 2010, p. 8).

Analysing deposit activity of MFIs in the regions, there is some relationship between the volume of deposit in these institutions and the level of development of the countries (Table 1). For example, in Latin America the volume of deposits in MFIs as a percentage of GDP and the gross national income (GNI) per capita amount to: in Bolivia 4.98\% and 4 510, in Peru $1.90 \%$ and 8270 , in Mexico $0.07 \%$ and 13 650. Thus, it is seen that the smaller GNI per capita characterises the economy in Latin America the larger volume of deposits in MFIs as a percentage of GDP is in the country. In Africa, however, it is difficult to define these ties (Table 1). Nevertheless, the volume of deposits is positively determined by the number of MFIs branches available to their clients (Table 1). 
Table 1. Characteristics of MFIs activity against a background of gross national income (GNI) per capita (USD, PPP) in chosen countries in 2009

\begin{tabular}{|c|c|c|c|c|c|c|}
\hline \multirow[b]{2}{*}{ Country } & \multicolumn{5}{|c|}{ Microfinance institutions } & \multirow[b]{2}{*}{$\begin{array}{l}\text { GNI per } \\
\text { capita }\end{array}$} \\
\hline & No.* & $\begin{array}{c}\text { Deposits } \\
\text { as \% of } \\
\text { GDP }\end{array}$ & $\begin{array}{l}\text { Loans } \\
\text { as \% of } \\
\text { GDP }\end{array}$ & $\begin{array}{l}\text { Branches } \\
\text { per } 100000 \\
\text { adults }\end{array}$ & $\begin{array}{c}\text { Borrowers } \\
\text { as \% of the } \\
\text { poor* }\end{array}$ & \\
\hline \multicolumn{7}{|c|}{ Europe } \\
\hline Bosnia and Herz. & 15 & $-^{* *}$ & 2.47 & 12.60 & 55 & 8880 \\
\hline Georgia & 9 & - & 0.61 & 14.18 & 5 & 4720 \\
\hline \multicolumn{7}{|c|}{ South America } \\
\hline Bolivia & 30 & 4.98 & 5.02 & 4.96 & 12 & 4510 \\
\hline Mexico & 98 & 0.07 & 0.07 & 1.05 & 21 & 13650 \\
\hline Panama & 9 & 0.32 & 0.38 & 0.54 & 2 & 12210 \\
\hline Peru & 89 & 1.90 & 2.40 & 3.78 & 18 & 8270 \\
\hline \multicolumn{7}{|c|}{ Asia } \\
\hline Bangladesh & 238 & 3.62 & 4.13 & 2.36 & 41 & 1710 \\
\hline Indonesia & - & 0.33 & 0.52 & 0.58 & - & 3940 \\
\hline Nepal & 66 & 0.20 & 0.84 & 1.94 & 11 & 1170 \\
\hline Pakistan & 32 & 0.05 & 0.15 & 1.42 & 3 & 2680 \\
\hline Philippines & - & 0.02 & 0.02 & 0.47 & - & 3720 \\
\hline Syria & 2 & 0.00 & 0.03 & 0.06 & 0 & 5080 \\
\hline \multicolumn{7}{|c|}{ Africa } \\
\hline Botswana & 1 & 0.00 & 0.00 & 1.11 & 0 & 13060 \\
\hline Burundi & 7 & 0.34 & 0.45 & 0.47 & 1 & 400 \\
\hline Ethiopia & 22 & 0.67 & 1.43 & 0.96 & 5 & 960 \\
\hline Ghana & 65 & 2.00 & 1.16 & 3.17 & 7 & 1530 \\
\hline Kenya & 28 & 3.06 & 0.13 & 0.02 & 5 & 1590 \\
\hline Madagascar & 13 & 0.33 & 0.52 & 2.99 & 1 & 960 \\
\hline Uganda & 29 & 0.12 & 0.33 & 0.47 & 3 & 1220 \\
\hline Yemen & - & 0.00 & 0.42 & 0.27 & - & 2400 \\
\hline Zambia & 6 & 0.01 & 0.58 & 1.56 & 0 & 1310 \\
\hline
\end{tabular}

*-January 1, 2009. **-data not available.

Source: own study based on databases of: Microfinance Information Exchange, Inc., The World Bank; (Financial... 2010, pp. 63).

In Bolivia, the larger volume of deposits in MFIs (4.98\% of GDP) accompanies the larger number of MFIs branches (4.68 per 100000 adults). However, these indicators amount in: Panama $-0.32 \%$ and 0.54 , Philippines 
$-0.02 \%$ and 0.47 , Ethiopia $0.67 \%$ and 0.96 . Moreover, as it was mentioned, MFIs in contrast to commercial banks operate, to a larger extent, in rural areas. Therefore, in 2009 only $26 \%$ of branches of commercial banks were located there, in comparison to $42 \%$ branches of MFIs (Financial... 2010, p. 14).

We can also see the diverse regional distribution of the MFIs poor borrowers (Table 1). In 2009, an interesting situation was in Bosnia and Herzegovina, where 15 MFIs granted microcredits to the $55 \%$ of people living below the poverty line. The second analysed country where MFIs concentrated on the poor was Bangladesh. In turn, in Africa these ratios were relatively low (Table 1 ).

As far as the credit activity is concerned, global financial crisis influenced on the decline of loan volume. In 2009, in about $85 \%$ of economies there was a slowdown. Between 2008 and 2009, the biggest decline in the ratio commercial-bank-loans to GDP was in Europe and Central Asia region (27\%), whereas the smallest in East Asia and Pacific region (9\%). Some research indicate that loan volume is mainly determined by population density, branch penetration, physical infrastructure indicators, such as phone lines per capita as well as financial infrastructure, such as credit information or creditor rights. Thus, the smallest decrease of commercial banks loans as a percentage of GDP was in highly developed OECD countries (decline of 9\%).

Commercial banks have also the largest branch network. In 2009 their share in all financial institution branches was $66 \%$ in comparison to $2 \%$ of MFIs and $23 \%$ of cooperatives (Financial... 2010, pp. 9-13). So, in the field of credit activity MFIs may compete more effectively with commercial banks in rural areas or small towns.

Similarly to deposits, mutual relationships can be found between the level of credit activity of MFIs and the gross national income per capita in each country. So, in many cases the smaller GNI per capita is, the larger volume of loans of MFIs as a percentage of GDP in the country is granted. Unlike deposits, this tie is stronger in the African countries (Table 1). In 2009, in African countries the largest market of microcredits was in Ethiopia, which was characterised by low GNI per capita (Table 1). Moreover, there is the most numerous group of MFIs clients. In 2008 in Ethiopia, there were about 1.8 million of borrowers in contrast to 0.9 million in Kenya, 0.6 million in South Africa or 0.4 million in Nigeria. In consequence, in Africa still only about $1 \%$ of its population borrows money from microfinance sector (Helmore et al. 2009, p. 9).

Additionally, between 2007 and 2009, the research conducted on a sample of MFIs in India showed the increase of the yield from $21.5 \%$ to $29 \%$ there. It was a result of the growth of the cost of borrowing from $10.5 \%$ 
in 2008 to $12.1 \%$ in 2009 there (Parameshwar et al. 2010, p. 3). Accordingly, the growth of the loan interest rates in MFIs determined accessibility of the loans for the poor. This growth also influenced on the rise of the nonperforming credits or some problems with the capital structure in MFIs. Furthermore, the increase of interest rates limited the microcredits for the low-income individuals, both households and entrepreneurs. Muhammad Yunus, the Nobel Prize Laureate, said that the financial crisis has not hit the microfinance system (Everett 2013). Nevertheless, the influence of the financial markets on the real economy, especially through high interest rates, decreased the growth of the expansion of these institutions. There were some other economic indicators which strongly determined the microfinance activity between 2007-2010, such as: volume of GDP/GNI, unemployment rate, level of household incomes or range of business activity. Accordingly, the deterioration of these issues resulted in a worse situation of the microfinance activity. Furthermore, in that period, in individual countries the functioning of MFIs, especially their worse financial results, was tied with (Erceg 2010, pp. 3-4; Lützenkirchen, Weistroffer 2012, p. 2; Microfinance crises... 2013, Di Bella 2011, p. 11):

- political climate in the country - example of violent protests in Nicaragua in 2008 that forced the MFIs branches to close;

- over-indebtedness of the clients - example of Southern India in 2010 or Bosnia and Herzegovina in 2009;

- unreasonable policy of the regulator in granting the licenses for this activity - example of Nigeria, where before 2007 the Central Bank awarded hundreds of licenses to banks in order to create a large microfinance sector. However, most of these institutions were not adequately prepared to serve low-income clients and focused on deposit taking rather than money lending. As a result, they created the liquidity crisis there;

- credit oversupply in some markets;

- excessive profit-orientation rather than social goals, which raised moral hazard among the staff of MFIs and their clients;

- environmental catastrophes - example of Pakistan in 2010, where floods caused losses in homes, crops and livestock, worsening repayments of the loans.

It should be underlined that some of these issues appeared, inter alia, as results of the growth of the interest rates and loosening of the loan policy by the MFIs. On the other hand, these problems concerned especially rural areas.

However, recent financial crisis caused consolidation movements in the microfinance sector. Lots of MFIs also changed their legal structure from typical non-profit MFIs to non-banking financial companies, which can 
attract equity and debt capital, human resources and clients at a fast rate (Parameshwar et al. 2010, p. 1). In turn, in Pakistan, the Central Bank has encouraged the commercialization of the MFIs in order to achieve the growth of their clients (Llanto, Badiola 2009, p. 58). Consequently, between 2007 and 2010 the number of borrowers in microfinance banks and other MFIs increased from 1.47 million to 2.01 million individuals there (Strategic... 2011, p. 4). But G. Nsabimana said that most MFIs still did not possess enough skills in treasury management. In a result, it determines the risk of their functioning. In 2012, the Centre for the Study of Financial Innovation published that, on a scale of 1 to 10, in a global perspective MFIs can handle the risk they had identified at the level of 5.59. The largest level of this indicator was for MFIs located in Latin America, whereas the smallest in Europe (Central and Eastern Europe - 5.07 and Western Europe 5.05) (Lascelles, Mendelson 2012, pp. 23, 36). Hence, Latin America emerged as the most confident region for the microfinance activity.

Furthermore, in many countries processes strengthening security of MFIs clients have appeared recently. For example in Nigeria, the government passed the law requiring all deposit-taking MFIs to meet a set of criteria established for microfinance banks. These regulations implied that all former community banks had to meet the requirements and re-registered as microfinance banks. In a result, 730 microfinance banks had been licenced until April 2008 there (Helmore et al. 2009, p. 19).

\section{Conclusions}

Summarising, the activity of MFIs is strongly determined by the situation in the real economy or even political aspects in the countries. Eruption of the global financial crisis in late 2007 only disclosed unreasonable issues of the functioning of this sector. The after-effects of this crisis, especially an increase of interest rates, negatively influenced the solvency of their clients and costs of the borrowed capital. There were some mistakes, as it was mentioned, inside MFIs, as well as inappropriate activity of the regulators, which differed between the countries.

Moreover, we can observe the reorientation of the goals of MFIs activity from social-oriented to profit-oriented aims. So, the financial crisis undoubtedly constrained the process of intensive development of MFIs. Nevertheless, there is still a huge market niche for these institutions. As it was characterised, deposits and loans of MFIs do not possess the substantial share in economies worldwide. These indicator also differed both between the countries and continents. Accordingly, MFIs should still concentrate on the rural regions, where there is less competition from the side of 
commercial banks. Particularly, positive aspects of their functioning ought to be exploited in the African countries. The structure of this region and its economic condition could be conductive to develop the microfinance sector there, oriented on its original goals. Thus, in these countries, regulations should be implemented which could support the development of the socialoriented MFIs (mainly promoting employment), rather than companies that exploit the lack of the capital of the poor. Moreover, some national regulators should take legal actions in order to protect the MFIs clients from the over-indebtedness. However, the terms "microfinance' or "microfinance institution" should not be abused to describe every type of activity of nonbanks. The core concept of this industry is not the delivery of the financial assistance to everyone but, first and foremost, the financial support for people living below the poverty line in order to combat it.

\section{References}

Armendáriz de Aghion B., Mordoch J. (2005), The economics of microfinance, The MIT Press Cambrige, London.

Carboni B.J., Calderon M.L., Garrido S.R., Dayson K., Kickul J. (2010), Handbook of microcredit in Europe: social inclusion through microenterprise development, Edward Elgar, Cheltenham-Northampton.

Churchill C., Frankiewicz C. (2006), Making Microfinance Work: Managing for Improved Performance, International Labour Office, Geneva.

Christen R.P., Rosenberg R., Jayadeva V. (2004), Financial institutions with $a$,double bottom line”: implications for the future of microfinance, „Occasional Paper", No. 8.

Databases of: Microfinance Information Exchange, Inc. (microfinance indicators), The World Bank (GNI per capita).

Davis S., Dubitsky R. (2013), Microfinance meets Wall Street, http://www.forb es.com/2008/03/22/brac-microfinance-creditsuisse-oped-cx_sdrd_0326brac.html (10.01.2013).

Dellien H., Schreiner M. (2005), Credit scoring, banks, and microfinance: balancing high-tech with high-touch, "Microenterprise Development Review", Vol. 8, No. 2.

Dellien H., Burnett J., Gincherman A., Lynch E. (2005), Product diversification in microfinance: introducing individual lending, Women's World Banking, New York.

Di Bella G. (2011), The impact of the global financial crisis on microfinance and policy implications, "IMF Working Paper", No. 175.

Everett S. (2013), Microcapital story: the global financial crisis and microfinance, http://www.microcapital.org/microcapital-story-the-global-financial-crisis-andmicrofinance (10.01.2013).

Erceg B. (2010), Improving quality of credit portfolio, Association of Microfinance Institutions in Bosnia and Herzegovina, Sarajevo. 
Financial Access 2010. The state of financial inclusion through the crisis (2010), Consultative Group to Assist the Poor/The World Bank Group, Washington.

Forest S, Green S., Pytkowska J. (2003), The state of microfinance in Central and Eastern Europe and the New Independent States, CGAP, Washington DC.

Helmore K., Chidiac S., Hendricks L. (2009), Microfinance in Africa. State of the sector report, Cooperative for Assistance and Relief Everywhere, Atlanta.

Holtmann M. (2008), Use of security in challenging environments: the microfinance perspective [in:] Dahan F, Simpson J. (ed.), Secured transations. Reform and access to credits, Edward Elgar Publishing, Bodmin.

Jansson T. (2001), Microfinance: from village to wall street, Inter-American Development Bank, Washington.

Karnani A. (2007), Microfinance misses its mark, "Stanford Social Innovation Review", No. 3.

Karnani A. (2008), Romanticizing the poor harms the poor, "The Whitehead Journal of Diplomacy and International Relations", Vol. 9.

Lascelles D., Mendelson S. (2012), Microfinance Banana Skins 2012. The CSFI survey of microfinance risk, Centre for the Study of Financial Innovation, London.

Ledgerwood J. (1999), Microfinance handbook. An institutional and financial perspective, The World Bank, Washington D.C.

Llanto G.M., Badiola J.A.R. (2009), The impact of the global financial crisis on rural and microfinance in asia, "Philippine Institute for Development Studies Discussion Paper Series", No. 24.

Lützenkirchen C., Weistroffer C. (2012), Microfinance in evolution. An industry between crisis and advancement, „Deutsche Bank Research“, September 13.

Parameshwar D., Aggarwal N., Zanchi R., Shankar S.S. (2010), Indian MFIs: Growth for old new institutions alike, "The Micro Banking Bulletin”, No. 20.

Sengupta R., Aubuchon C.P. (2008), The microfinance revolution: an overview, "Federal Reserve Bank of St. Louis Review", No. 90.

The EIB Group and microfinance: promoting inclusive finance (2011), European Investment Bank, Luxembourg.

Tulchin D. (2004), Positioning microfinance institutions for the capital markets, "Social Enterprise Associates Working Paper", No. 5.

Strategic Framework for Sustainable Microfinance in Pakistan (2011), State Bank of Pakistan, Karachi.

Welle-Strand A., Kjфllesdal K., Sitter N. (2010), Assessing microfinance: the Bosnia and Herzegovina case, "Managing Global Transition", Vol. 8, No. 2.

6 microfinance crises that the sector does not want to remamber (2013), http://www.microfinancefocus.com/node/2816 (10.01.2013). 